\title{
POTENTIAL SIDE-EFFECTS OF A FERTILIZER ON GROWTH, BIOCHEMICAL COMPOSITION AND BIOMARKER RESPONSES OF THE GREY WORM (APORRECTODEA CALIGINOSA SAVIGNY, 1826)
}

\author{
Halaimia, S. ${ }^{1}-$ Tine, S. ${ }^{1,2}-$ Tine-DJebBaR, F. ${ }^{1,2^{*}}-$ Soltani, N. ${ }^{2}$ \\ ${ }^{1}$ Laboratory of Water and Environment, University of Tebessa, Tebessa, Algeria \\ ${ }^{2}$ Laboratory of Applied Animal Biology, University Badji Mokhtar, Annaba, Algeria \\ *Corresponding author \\ e-mail:fouzia.djebbar@univ-tebessa.dz
}

(Received $20^{\text {th }}$ Oct 2020; accepted $19^{\text {th }}$ Jan 2021)

\begin{abstract}
Earthworms are a major component of soil fauna communities in most ecosystems and comprise a large proportion of macro fauna biomass. They play multiple roles in soil heath. Earthworms represent one of the most important biological indicators in the terrestrial environment. However, they are exposed to agrochemicals used to increase crop yield. The present study was conducted to assess the potential hazards of a complete fertilizer (NPK), commonly used in agriculture, on juveniles of Aporrectodea caliginosa Savigny, 1826 an abundant species in the region of Tebessa (Northeast Algeria). The fertilizer was tested at different doses ranging between 400 and $1200 \mathrm{mg}$ on juvenile earthworm under laboratory conditions. Growth, biochemical composition (lipid, protein, and carbohydrate content) and four selected biomarkers of oxidative stress (glutathione peroxidase, lactate dehydrogenase, glutathione S-Transferase and glutathione) were examined weekly during an exposure of four weeks. The earthworm mortality was monitored after 4 weeks of exposure. The $\mathrm{LD}_{25}, \mathrm{LD}_{50}$ and $\mathrm{LC}_{90}$ values were 518.9, 644.9 and $996.4 \mathrm{mg}$, respectively. The tested fertilizer $\left(\mathrm{LD}_{25}\right.$ and $\left.\mathrm{LD}_{50}\right)$ showed inhibitory effects on the growth of A. caliginosa. Moreover, it resulted in a significant reduction in the energy reserves as evidenced by a reduction in carbohydrate, lipid and protein amounts. Lastly, enzymatic assays revealed a stimulation of the detoxification system traduced by an increase in glutathione peroxidase, lactate dehydrogenase and glutathione S- Transferase activities and a decrease in glutathione rate compared to control series. Overall results indicate that application of the fertilizer tested could have harmful effects on earthworms.
\end{abstract}

Keywords: ecosystem engineers, NPK fertilizer, growth rate, energy reserves, detoxification system, oxidative stress

\section{Introduction}

In order to increase crop yield, pesticides and fertilizers are now being used in higher quantities than in the past (Gill and Garg, 2014; Băcanu et al., 2019). When these agrochemicals enter the soil, they may disturb the soil ecosystems by impairing the physical, chemical and biological components specially the non-target beneficial microorganisms and earthworms (Edwards and Bohlen, 1992). Indiscriminate use of these products has led to many negative effects such as loss of top soil due to pollution by fertilizers, weedicides and pesticides, as well as magnification of chemicals in food chains and food webs (Shruthi et al., 2017). They are also responsible for extensive soil air and water pollution, and affect not only the target organisms, but also the nontargeted species such as earthworms. They constitute more than $80 \%$ of the invertebrate biomass in most of the agroecosystems of the world (Yasmin and D'Souza, 2010) and contribute to a number of soil properties, such as soil structure, porosity, water 
retention, cationic exchange and $\mathrm{pH}$ buffering capacity (Lal, 2004). Due to their beneficial role in the agroecosystem, earthworms are used as indicator species for monitoring the impact of pollutants, changes in soil structure and agricultural practices (Yasmin and D'Souza, 2010). Earthworms recognized as 'ecosystem engineers' are naturally in contact with the solid and aqueous phases of the soil, ingest large amounts of soil and are therefore directly exposed to contaminants, industrial activities and atmospheric deposition. However, their diversity, density and biomass are strongly influenced by soil management (Gill and Garg, 2014). Pelosi et al. (2014) reported that earthworms are affected at all levels of the organism; changed individual behaviors, disrupted metabolism and enzyme activities, increased individual mortality, reduced fertility, retardation of growth and reproduction. Several studies have been carried out on the toxic impact of some pesticides on soil organisms, especially earthworms, although little research has been done on the toxicity of different fertilizers to earthworms in a soil profile (Yahyaabadi et al., 2018). A number of studies have found the positive effects of fertilizers on earthworms and their populations (Estevez et al., 1996; Curry et al., 2008). Few researchers also emphasized the negative effects of chemical fertilizers on earthworms (Tindaon et al., 2011; Bhattacharya and Sahu, 2014). Both beneficial (Callaham et al., 2003) and harmful effects (Marhan and Scheu, 2005) of inorganic fertilizers on earthworm populations have been reported from different agroecosystems. Several studies were conducted on the toxicity of NPK using earthworms as test animal by Paper contact method (Abbiramy and Ross, 2013a, b; Bhattacharya and Sahu, 2016). But very few studies were conducted to test the toxicity of NPK on the soil ecosystem. The use of biochemical biomarkers to investigate the contaminant toxicity, metabolization, and detoxification in earthworms is nowadays becoming a current practice (Denoyelle, 2007; Reinecke and Reinecke, 2007). The importance of antioxidant enzymes is generally emphasized in the prevention of oxidative stresses by scavenging of reactive oxygen species (ROS) (Lijun et al., 2005). The antioxidant system comprises several enzymes such as superoxide dismutase (SOD), catalase (CAT), and guaiacol peroxidase (GPx). Superoxide radicals that are generated are converted to $\mathrm{H}_{2} \mathrm{O}_{2}$ by the action of SOD, and the accumulation of $\mathrm{H}_{2} \mathrm{O}_{2}$ is prevented in the cell by CAT and GPx.

Our objective was to assess the potential hazards of a balanced fertilizer (NPK), widely used in agriculture, against Aporrectodea caliginosa an abundant earthworm species in Tébessa area (Northeast Algeria) (Bouazdia and Habes, 2017) and used as bioindicator of soil contamination. Thus, the fertilizer was tested on survival, growth, biochemical composition of the whole body and also on two selected environmental stress biomarkers (GPx and LDH). The purpose of this study was to obtain more comprehensive understanding of the effects of the fertilizers on earthworm, and to provide more information about the potential ecological risk agrochemicals on the soil ecosystem particularly beneficial and non-target fauna. The information obtained from this study is considered critical, as it will provide a foundation for risk assessment.

\section{Materials and methods}

\section{Earthworm collection and soil properties}

Earthworm populations were sampled at the end of autumn, which is known to be a period of great earthworm activity (Bouché, 1972). Population samples of the endogenic juvenile's earthworm's A. caliginosa L. were collected by hand from the region of El 
Merdja, located at $4.5 \mathrm{Km}$ northeast of the city of Tebessa (northeastern Algeria) $\left(35^{\circ} 25^{\prime} \mathrm{N}, 8^{\circ} 10^{\prime} \mathrm{E}\right.$; elevation: $830 \mathrm{~m}$ a.s.1.). 40 -cm-depth block of soil was excavated and earthworms were hand-sorted according to the method of Bouché (1972) from an upland non-irrigated paddy field which had no record of input of agrochemicals. After collection, the earthworms were cultured for 7 days of adaptation (Mekahlia et al., 2016) at their native soil. The experiment was maintained at $60 \pm 2 \%$ soil moisture and $25 \pm 2{ }^{\circ} \mathrm{C}$ soil temperature. The physical and chemical properties of the soil are shown in Table 1.

Table 1. Physical and chemical properties of the soil

\begin{tabular}{c|c}
\hline Properties & Results \\
\hline Texture & clay \\
$\mathrm{pH}$ & $8.68 \pm 0.01$ \\
Electronic conductivity & $335.5 \pm 3.5 \mu \mathrm{sm} / \mathrm{cm}$ \\
Organic matter & $11.86 \pm 0.4 \%$ \\
$\mathrm{CaCO} 3$ & $24.25 \pm 0.75 \%$ \\
\hline
\end{tabular}

Then, they were categorized into three age classes (juveniles, immature and adults) on the basis of size and presence or absence of genital papilla and clitellium (Bhattacharya and Sahu, 2016). Earthworms are considered sub-adult if they have a full tubercula pubertatis but no clitellum and adult if they are clitellate (Sims and Gerard, 1999). They are considered juvenile if they have neither tubercula pubertatis nor clitellum (Pelosi, 2008).

\section{Fertilizer and treatment}

Inorganic fertilizer was supplied from Agricultural Services Directorate of Tebessa area. Mixtures containing all the three principal nutrients $(\mathrm{N}, \mathrm{P}$ and $\mathrm{K})$ are termed complete fertilizers. NPK fertilizer contains: $15 \% \mathrm{~N}+15 \% \quad \mathrm{P}_{2} \mathrm{O}_{5}+15 \% \quad \mathrm{~K}_{2} \mathrm{O}$. The studies carried out in plastic containers of $20 \times 10 \times 7 \mathrm{~cm}$ (length $\times$ width $\times$ depth), were set up each with $500 \mathrm{gm}$ of native soil. Before the initiation of the exposure test, earthworms were rinsed in tap water and moved to Petri dishes on moist filter paper to void their gut contents.

Serial amounts of the dry powder (400 to $1200 \mathrm{mg}$ ) were prepared (Fig. 1A). These were added to the soil surface and then mixed thoroughly with enough water to ensure a homogeneous mixture (Fig. 1B). For the control treatment, distilled water was used. The test was carried out with 4 replicates each containing 10 earthworms per dose. The tested fertilizer was replaced weekly using the same concentration. The mortality was monitored by counting the number of dead earthworms at the end of different time periods $\left(1^{\text {st }}, 2^{\text {nd }}, 3^{\text {rd }}\right.$, and $4^{\text {th }}$ week $)$ and Finney's probit method was followed to calculate $\mathrm{LD}_{25}, \mathrm{LD}_{50}$ and $\mathrm{LD}_{90}$ values.

Earthworms were considered dead if they showed any of the following statuses: disappeared, lacking movement and no response to a definite tactile stimulus (Zheng et al., 2016). The choice of doses was made according to studies of Shruthi et al. (2017) and on the basis of the high mortality rate observed after treatment with the recommended agricultural dose (RAD corresponding to $\left.\mathrm{LD}_{90}\right)$. 

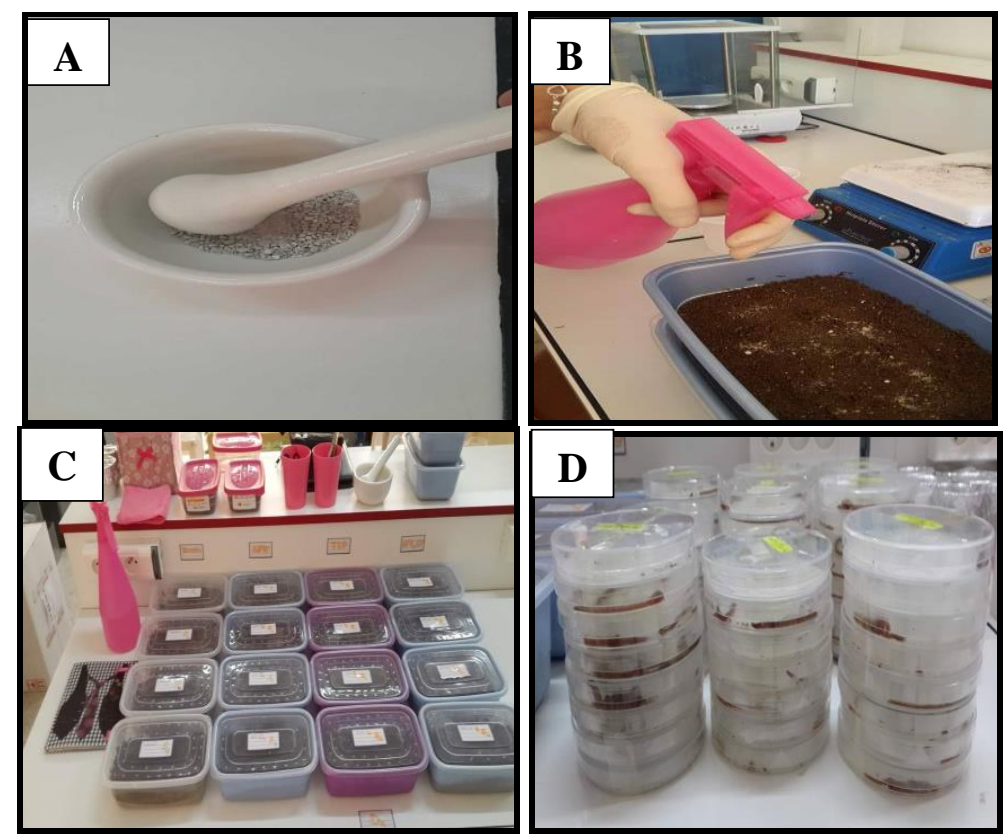

Figure 1. Experimental protocol. (A) Preparation of fertilizer (powder). (B) Treatment of the soil. (C) Earthworm rearing and treatment. (D) Voiding of the earthworm

\section{Performance test}

Ten individual earthworms were added to each plastic container and the sets were subdivided as follows; five plastic containers were applied for a control test with only water and 10 others were treated with two doses of NPK, corresponding to the $\mathrm{LD}_{25}$ and $\mathrm{LD}_{50}$ respectively (Fig. $1 C$ ). During the test period, earthworms were separated from the test substrate, counted, cleaned with deionized water and blotted with filter paper. Then, they were weighed on weeks 1, 2, 3, and 4, using an electro-balance. All the replicates were examined on each sampling date and the worms then replaced in the containers.

The weights of earthworms in each concentration reported from the various exposure periods were then used to calculate the growth inhibition as follows Shi et al. (2007):

$$
G I n=\left(W_{0}-W_{t} / W_{0}\right) \times 100
$$

where GIn is the growth inhibition for dose group $n, W_{0}$ is the weight on day 0 and $W_{t}$ is the weight after $t$ days of exposure.

Specific growth rates for a specific interval (SGR) were calculated by the formula:

$$
S G R n=(\ln W j-\ln W i) /(t j-t i)
$$

where SGRn is the specific growth rate for a specific interval for dose group $\mathrm{n}$ from day $\mathrm{i}$ to $\mathrm{j}$, Wi is the weight on day $\mathrm{i}$ and $\mathrm{Wj}$ is the weight after $\mathrm{j}$ days of exposure (OECD, 2006).

\section{Determination of biochemical composition}

Specimens of both treated $\left(\mathrm{LD}_{25}\right.$ and $\left.\mathrm{LD}_{50}\right)$ and control earthworms removed from the soil, were cleaned with deionized water, and moved to Petri dishes on moist filter 
paper to void their gut contents (Fig. 1D). One earthworm was selected from each container to determine biochemical composition at the tested period (i.e., at $1^{\text {st }}, 2^{\text {nd }}, 3^{\text {rd }}$, and $4^{\text {th }}$ week).

The main components (proteins, carbohydrates and lipids) were extracted following the procedure of Shibko et al. (1967). Fragments of the body $(50 \mathrm{mg}$ ) were extracted in $1 \mathrm{ml}$ of TCA $(20 \%)$. In brief, quantification of proteins was carried following the Coomassie Brilliant Blue G-250 dye-binding method of Bradford (1976) with bovine serum albumin as a standard. The absorbance was measured at $595 \mathrm{~nm}$. Carbohydrates were determined as described by Duchateau and Florkin (1959) using anthrone as reagent and glucose as standard. Lipids were measured by the vanillin method of Goldsworthy (1972) and the table oil (99\% triglycerides) used as a standard. Data were expressed in $\mu \mathrm{g}$ per mg of fresh tissue and assays conducted with 3 replicates per treatment.

\section{Glutathione peroxidase assay (GPx)}

The same sample preparation protocol was followed for the biomarkers assay. GPx assay was performed according to Flohe and Gunzler (1984). Fragments of the body $(50 \mathrm{mg})$ of control and treated earthworm $\left(\mathrm{LD}_{25}\right.$ and $\left.\mathrm{LD}_{50}\right)$ were homogenized in $1 \mathrm{ml}$

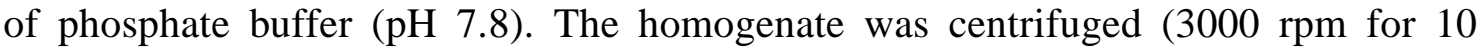
min), and the supernatant was recovered as an enzyme source. The assay was performed on an aliquot of $200 \mu \mathrm{l}$ of supernatant added to $400 \mu \mathrm{l}$ of the GSH solution (0.2 mM, pH 10). Absorbance reading was performed after $5 \mathrm{~min}$ at $412 \mathrm{~nm}$. Data were expressed in $\mu \mathrm{M}$ per min per mg of protein and assays conducted with 3 replicates per treatment.

\section{Lactate dehydrogenase assay ( $\mathrm{LDH})$}

The determination was based on the conversion of lactate to pyruvate or pyruvate to lactate. The assay of LDH was conducted according to the method of Hill and Levi (1954) as previously described (Sifi and Soltani, 2019) using NAD (nicotinamide adenine dinucleotide) as substrate. Fragments of the body $(50 \mathrm{mg})$ of control and treated earthworm $\left(\mathrm{LD}_{25}\right.$ and $\left.\mathrm{LD}_{50}\right)$ were homogenized in $1 \mathrm{ml}$ of Tris/ $\mathrm{HCl}(0.1 \mathrm{M}, \mathrm{pH}$ 7.2). The homogenate was centrifuged (3000 rpm for $5 \mathrm{~min}$ ) and then the supernatant recovered for use as enzyme source. The assay was performed with $50 \mu 1$ of supernatant added to $675 \mu \mathrm{l}$ of substrate buffer $(0.2 \mathrm{M}, \mathrm{pH} 10)$ and $50 \mu 1$ of NAD solution. The absorbance reading was done every minute for $5 \mathrm{~min}$ at $340 \mathrm{~nm}$. Data was expressed in $\mu \mathrm{M}$ per min per $\mathrm{mg}$ of protein and assays conducted with 3 replicates per treatment.

\section{Glutathione S-transferase assay (GST)}

The assay of GST was carried out according to Habig et al. (1974) previously described (Dris et al., 2017) with use of GSH (5 mM). Fragments of the body (50 mg) of control and treated earthworm $\left(\mathrm{LD}_{25}\right.$ and $\left.\mathrm{LD}_{50}\right)$ were homogenized in $1 \mathrm{ml}$ phosphate buffer (0.1 M, pH 6). The homogenate was centrifuged (14000 rpm for $30 \mathrm{~min}$ ). $200 \mu \mathrm{l}$ of the resulting supernatant was added to $1.2 \mathrm{ml}$ of the mixture GSH-CDNB in phosphate buffer $(0.1, \mathrm{pH} 7)$. Changes in absorbance were measured at $340 \mathrm{~nm}$ every minute for a period of $5 \mathrm{~min}$. Data was expressed in $\mathrm{nM}$ per min per $\mathrm{mg}$ of protein and assays conducted with 3 replicates per treatment. 


\section{Glutathione assay (GSH)}

The assay of GSH was conducted according to the method of Weckberker and Cory (1988) previously used (Maiza et al., 2013). Fragments of the body (50 mg) of control and treated earthworm $\left(\mathrm{LD}_{25}\right.$ and $\left.\mathrm{LD}_{50}\right)$ were homogenized in $1 \mathrm{ml}$ of EDTA $(0.02 \mathrm{M}$, $\mathrm{pH}$ 6). The homogenate was subjected to a deproteinization with sulfosalysilic acid (SSA) at $0.25 \%$. The optical density was measured at $412 \mathrm{~nm}$. Data were expressed in $\mu \mathrm{M}$ per mg of protein and assays conducted with 3 replicates per treatment.

\section{Statistical analysis}

Data are presented as a mean value \pm SEM (standard error mean) in each treatment group. The normality of data was verified using the Kolmogorov-Smirnov test, and the homogeneity of variances was checked by Levene's test. Comparison of the experimental groups was tested by analysis of variance (ANOVA), and means were tested for statistical significance by a post hoc Tukey's honestly significant difference test. The statistical tests were performed using GraphPad Prism, version 7.00 (GraphPad Software, San Diego, CA, USA), where $\mathrm{p}<0.05$ indicates a statistically significant difference.

\section{Results}

\section{Effect on juvenile earthworm}

Different doses of NPK fertilizer: 400, 500, 600, and $1200 \mathrm{mg}$ were applied on juvenile earthworm of $A$. caliginosa exhibited toxicity. The mortality was scored at 4weeks after treatment. There was a wide variation in toxicity of NPK on juvenile earthworm with respect to dose conducted in five replicates. About $6 \%$ mortality of earthworms were recorded when they were exposed to $400 \mathrm{mg}$ of NPK in all the five replicates. The mortality increased to $24 \%$ when they were exposed to $500 \mathrm{mg}$ of NPK followed by $40 \%$ at $600 \mathrm{mg}$, and $96 \%$ of the juvenile earthworms died at $1200 \mathrm{mg}$ of NPK. Lethal doses $\left(\mathrm{LD}_{25}, \mathrm{LD}_{50}\right.$ and $\left.\mathrm{LD}_{90}\right)$ values with $95 \%$ confidence limit for juvenile earthworm were of 518.9, 644.9 and $996.4 \mathrm{mg}$ respectively (Table 2). No mortality was reported in control series.

Table 2. Toxicity test for A. caliginosa exposed to different doses of NPK

\begin{tabular}{c|c|c|c|c|c|c}
\hline $\begin{array}{c}\text { Doses } \\
(\mathbf{m g})\end{array}$ & Mortality (\%) & $\begin{array}{c}\mathbf{L D}_{\mathbf{2 5}} \\
\mathbf{( 9 5 \%} \mathbf{~ F L )}\end{array}$ & $\begin{array}{c}\text { LD } \\
(\mathbf{9 5 \%} \text { FL) }\end{array}$ & $\begin{array}{c}\text { LD } \\
(\mathbf{9 5 \%} \text { FL) }\end{array}$ & HillSlope & $\mathbf{R}^{\mathbf{2}}$ \\
\hline 400 & $6.00 \pm 4.80 \mathrm{a}$ & & & & & \\
500 & $24.00 \pm 4.80 \mathrm{~b}$ & $\mathbf{5 1 8 . 9}$ & $\mathbf{6 4 4 . 9}$ & $\mathbf{9 9 6 . 4}$ & 0.507 & 0.99 \\
600 & $40.00 \pm 4.00 \mathrm{~b}$ & $(479.1$ to 557.3$)$ & $(598.6$ to 710.8$)$ & $(801.2$ to 1284$)$ & & \\
1200 & $43.00 \pm 9.08 \mathrm{c}$ & & & & & \\
\hline
\end{tabular}

\section{Effect on growth}

Specific growth rate of earthworms is shown in Figure 2A, positive Specific growth rate means the weight of earthworms increased, and negative ones represent growth inhibition of earthworms at specific intervals. The SGR of the earthworms in both dosetreated during all the exposure intervals exposed to NPK were negative. With the time increase, the specific growth rates decreased at all tested periods: $0-1$ week $\left(F_{2}\right.$, 
$12=46.53 ; \mathrm{p}<0.001), 1-2$ week $\left(\mathrm{F}_{2,12}=18.57 ; \mathrm{p}<0.001\right), 2-3$ week $\left(\mathrm{F}_{2}, 12=17.95\right.$; $\mathrm{p}<0.001)$ and $3-4$ week $\left(\mathrm{F}_{2,12}=103.3 ; \mathrm{p}<0.001\right)$.

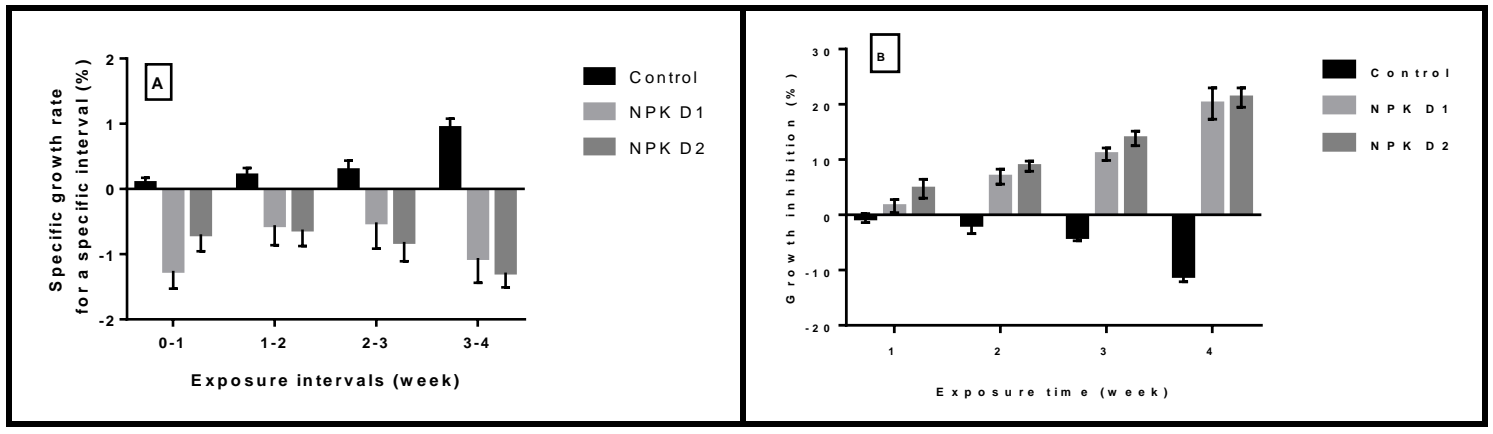

Figure 2. Effects of fertilizer administrated at two doses on specific growth rate (\%) (A) and growth inhibition (\%) (B) in juvenile of A. caliginosa (mean $\pm S E M, n=5$ repeats, each containing 10 individuals)

The growth inhibition of earthworms at 1,2,3, and 4 weeks for the two doses of fertilizer are shown in Figure $2 \mathrm{~B}$. Under the experimental conditions used here, the growth inhibition for the controls was negative. The fertilizer showed inhibitory effects on the gain of weight at the first $\left(\mathrm{F}_{2,12}=21.39: \mathrm{p}<0.001\right)$, the second $\left(\mathrm{F}_{2,12}=88.64\right.$ : $\mathrm{p}<0.001)$, the third $\left(\mathrm{F}_{2,12}=393.3: \mathrm{p}<0.001: \mathrm{p}<0.001\right)$ and the fourth week $\left(\mathrm{F}_{2,12}=409.3: \mathrm{p}<0.001\right)$ with a dose relationship at the first (Dose 1 vs Dose 2: $\mathrm{p}=0.0059$ ) and the third week (Dose 1 vs Dose $2: \mathrm{p}=0.0032$ ).

\section{Effects on biochemical components}

Changes in main biochemical components (lipids, carbohydrates and proteins) were determined in whole body of $A$. caliginosa juveniles at different times of exposure $\left(1^{\text {st }}\right.$ week, $2^{\text {nd }}$ week, $3^{\text {rd }}$ week and $4^{\text {th }}$ week) to tested doses (500 and $600 \mathrm{mg}$ ) (Figs. 3, 4 and 5).

According to ANOVA test, results showed a significant decrease $(\mathrm{p}<0.001)$ in the lipid contents in both treated series (Dose 1 and Dose 2) as compared to controls during all tested exposure time with a dose-response relationship: $1^{\text {st }}$ week $\left(\mathrm{F}_{2,6}=38.36\right.$; $\mathrm{p}<0.001), 2^{\text {nd }}$ week $\left(\mathrm{F}_{2,6}=363.1 ; \mathrm{p}<0.001\right), 3^{\text {rd }}$ week $\left(\mathrm{F}_{2,6}=69.09 ; \mathrm{p}<0.001\right)$ and $4^{\text {th }}$ week $\left(\mathrm{F}_{2,6}=4609 ; \mathrm{p}<0.001\right)$.

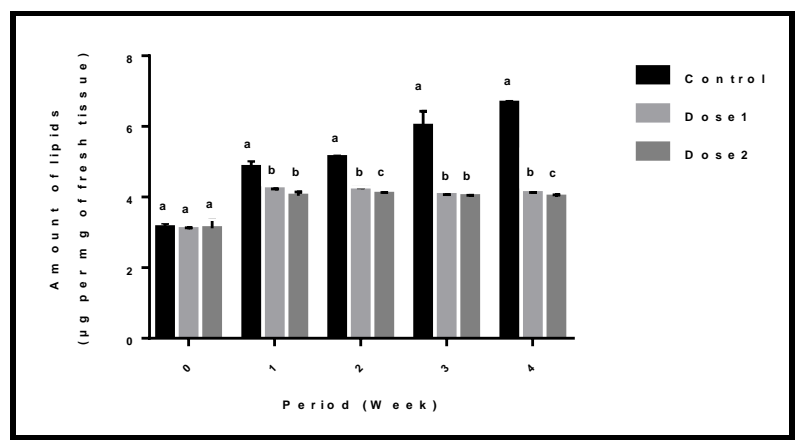

Figure 3. Effects of fertilizer applied at two doses on amounts ( $\mu \mathrm{g}$ per mg of fresh tissue) of lipids in juvenile of A. caliginosa during the exposure period (mean $\pm S E M, n=3$ repeats each containing $50 \mathrm{mg}$ of fresh tissue). The different lowercase letters indicate significant differences at the same time based on Tukey's HSD test $(p<0.05)$ 


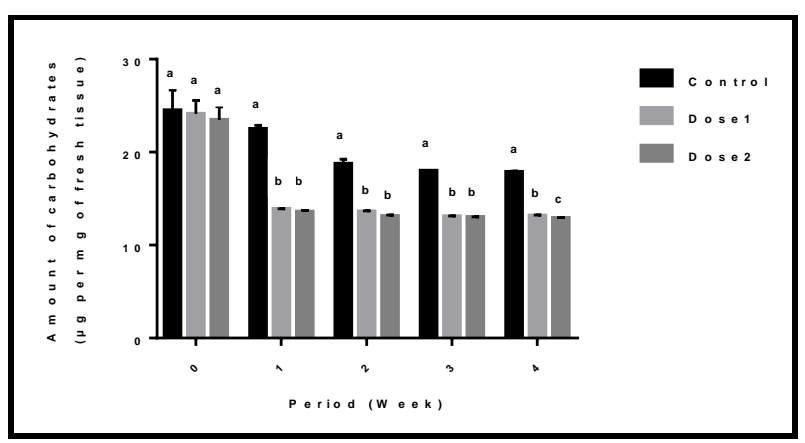

Figure 4. Effects of fertilizer applied at two doses on amounts ( $\mu \mathrm{g}$ per $\mathrm{mg}$ of fresh tissue) of carbohydrates in juvenile of A. caliginosa during the exposure period (mean $\pm S E M, n=3$ pools each containing $50 \mathrm{mg}$ of fresh tissue). The different lowercase letters indicate significant differences at the same time based on Tukey's HSD test ( $p<0.05)$

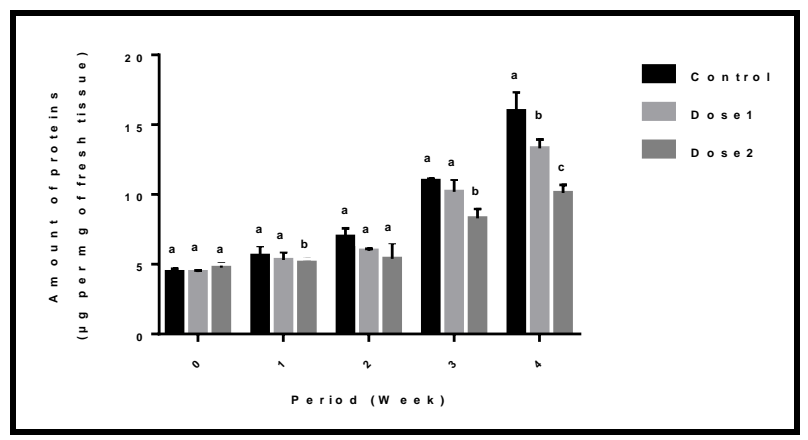

Figure 5. Effects of fertilizer applied at two doses on amounts ( $\mu \mathrm{g}$ per $m g$ of fresh tissue) of proteins in juvenile of A. caliginosa during the exposure period (mean $\pm S E M, n=3$ repeats each containing $50 \mathrm{mg}$ of fresh tissue). The different lowercase letters indicate significant differences at the same time based on Tukey's HSD test ( $p<0.05)$

The carbohydrate contents decreased significantly at the $1^{\text {st }}\left(\mathrm{F}_{2,6}=1247, \mathrm{p}<0.001\right)$, the $2^{\text {nd }}\left(\mathrm{F}_{2,6}=324.3 ; \mathrm{p}<0.001\right)$ and the $3^{\text {rd }}$ week $\left(\mathrm{F}_{2,6}=28509 ; \mathrm{p}<0.001\right)$ without dose-response relationship and at the $4^{\text {th }}$ week $\left(\mathrm{F}_{2,6}=4218 ; \mathrm{p}<0.001\right)$ with a doseresponse relationship (Dose 1 vs Dose $2: \mathrm{p}=0.035$ ).

Lastly, concerning the protein rates, results showed a significant decrease at $1^{\text {st }}$ week $\left(\mathrm{F}_{2,6}=5.23, \mathrm{p}=0.048\right)$ and $3^{\text {rd }}$ week $\left(\mathrm{F}_{2,6}=13.48 ; \mathrm{p}=0.006\right)$ with the highest dose (Dose 2$)$ and at $4^{\text {th }}$ week $\left(\mathrm{F}_{2,6}=29.16 ; \mathrm{p}<0.001\right)$ with a dose-response relationship (Dose 1 vs Dose 2; $\mathrm{p}=0.014$ ).

\section{Effects on biomarkers}

Results of the specific activities of antioxidant defense enzyme (GPx, LDH and GST) and a cofactor GSH in A. caliginosa are summarized in Figures 6, 7, 8 and 9. They show that values are very similar in different tested periods. GPx activity increased significantly with the two doses at the first (Control vs Dose 1: $p=0.038$; Control vs Dose 2: $p=0.017$ ) and the fourth week (Control vs Dose 1: $p=0.033$; Control vs Dose 2: $\mathrm{p}=0.013$ ) without dose-response relationship. At the third week, an activation of GPx was observed with the highest dose (Dose 2) $(\mathrm{p}=0.024)$. No effect of the NPK was reported with the two doses applied $(\mathrm{P}>0.05)$ at the second week. 
Concerning LDH activity, a significant increase was observed in first, second, third and fourth week with the highest dose compared to controls $(\mathrm{p}=0.002 ; 0.001 ; 0.002$ and 0.005 respectively). No effect of the product was reported with the lowest applied dose $(\mathrm{P}>0.05)$ in all tested periods.

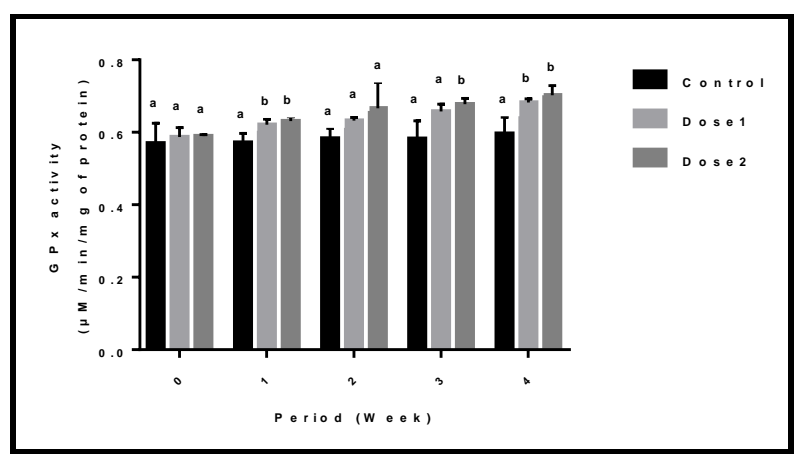

Figure 6. Effects of fertilizer applied at two doses on GPx activity $(\mu \mathrm{m} / \mathrm{min} / \mathrm{mg}$ of protein) in juvenile of A. caliginosa during the exposure period (mean $\pm S E M, n=3$ repeats each containing $50 \mathrm{mg}$ of fresh tissue). The different lowercase letters indicate significant differences at the same time based on Tukey's HSD test $(p<0.05)$

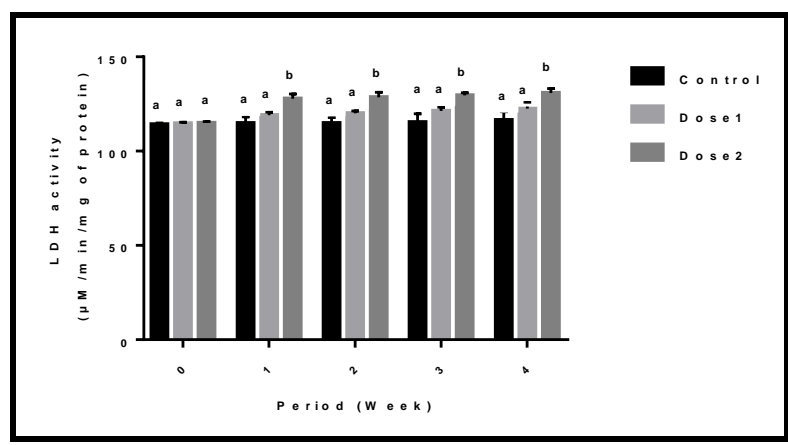

Figure 7. Effects of fertilizer applied at two doses on LDH activity ( $\mu M / \mathrm{min} / \mathrm{mg}$ of protein) in juvenile of A. caliginosa during the exposure period (mean $\pm S E M, n=3$ pools each containing $50 \mathrm{mg}$ of fresh tissue). The different lowercase letters indicate significant differences at the same time based on Tukey's HSD test ( $p<0.05)$

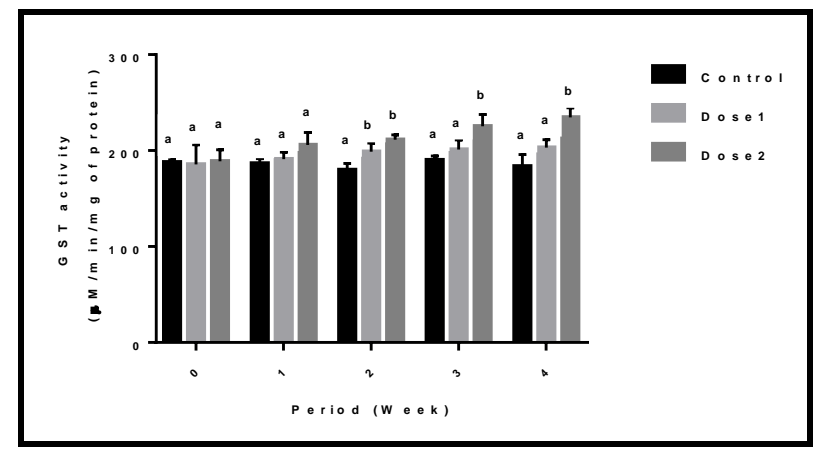

Figure 8. Effects of fertilizer applied at two doses on GST activity (nM/min/mg of protein) in juvenile of A. caliginosa during the exposure period (mean $\pm S E M, n=3$ repeats each containing $50 \mathrm{mg}$ of fresh tissue). The different lowercase letters indicate significant differences at the same time based on Tukey's HSD test $(p<0.05)$ 


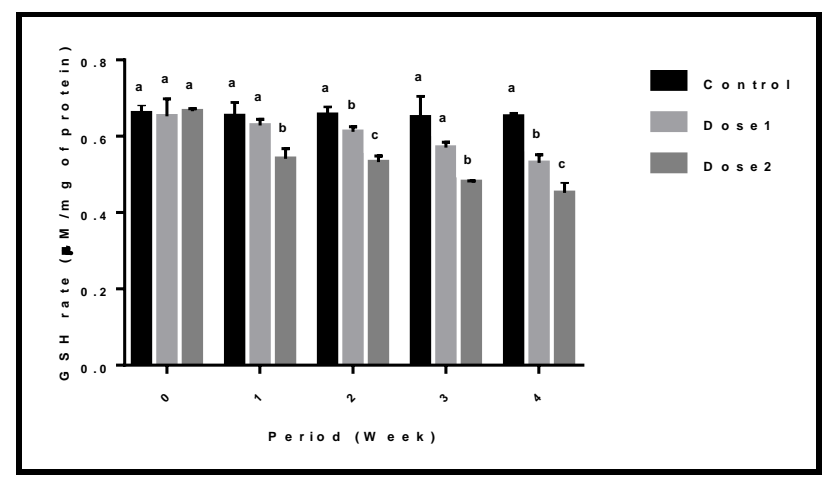

Figure 9. Effects of fertilizer applied at two doses on GSH rate ( $\mu M / m g$ of protein) in juvenile of A. caliginosa during the exposure period (mean \pm SEM, $n=3$ pools each containing $50 \mathrm{mg}$ of fresh tissue). The different lowercase letters indicate significant differences at the same time based on Tukey's HSD test $(p<0.05)$

Results of the specific activity of GST in A. caliginosa exposed to two doses of NPK fertilizer showed a significant increase in GST activity at the second month with two tested doses (Control vs Dose 1: $\mathrm{p}=0.038$; Control vs Dose 2: $\mathrm{p}=0.0039$ ) and the third (Control vs Dose 2: $\mathrm{p}=0.009$; Dose 1 vs Dose 2: $\mathrm{p}=0.046$ ) and the fourth month with the highest dose (Control vs Dose 2: $p=0.002$; Dose 1 vs Dose 2: $p=0.023$ ) respectively as compared to control series.

Finally, our results showed a significant decrease in the rate of GSH in the treated series at the first (Control vs Dose 2: $p=0.005$; Dose 1 vs Dose 2: $p=0.01$ ) and the third month with the highest dose (Control vs Dose 2: $\mathrm{p}=0.001$; Dose 1 vs Dose 2: $\mathrm{p}=0.037$ ) as compared to control series respectively. In addition, we note a significant decrease of GSH rate at the second (Control vs Dose 1: $p=0.041$; Control vs Dose 2: $\mathrm{p}=0.0003$; Dose 1 vs Dose 2: $\mathrm{p}=0.003)$ and the fourth month (Control vs Dose 1: $\mathrm{p}=0.0009$; Control vs Dose 2: $\mathrm{p}<0.0001$; Dose 1 vs Dose 2: $\mathrm{p}=0.008$ ) with the two tested doses as compared to control series.

\section{Discussion}

\section{Effects on juvenile earthworm}

Mortality, growth inhibition and biochemical responses are typical indicators for assessing the toxic effects of chemicals on earthworms (Shi et al., 2007; Wu et al., 2011). Study found that the juvenile, immature and adult worms of Drawida willsi survived in soil containing up to 250,370 and $490 \mathrm{mg} / \mathrm{kg}$ of NPK respectively. But $100 \%$ mortality of juveniles were recorded when worms were exposed to concentration of $490 \mathrm{mg} / \mathrm{kg}$ of NPK. However, at a concentration of $640 \mathrm{mg} / \mathrm{kg}$ and $730 \mathrm{mg} / \mathrm{kg}, 96 \%$ of immature and $92 \%$ of adult mortality was observed respectively. Gradually the mortality increased with the increase of doses (Bhattacharya and Sahu, 2016).

The result of this study further demonstrates that the inorganic mineral fertilizer can also be toxic to earthworms when contacted directly (Abbiramy et al., 2013a). The results of Shruthi et al. (2017) revealed that, when the food material was incorporated with various inorganic fertilizers, there was wide variation among the treatments with respect to mortality of adult and juvenile Eudrilus eugeniae earthworms ranging from 
0.00 to 100 per cent. Little information has been generated on the toxicity of inorganic fertilizers to earthworms in sugarcane and agricultural eco-system (Shruthi et al., 2017).

\section{Effects on growth}

Earthworms provide key soil functions that favor many positive ecosystem services. These services are important for agroecosystem sustainability but can be degraded by intensive cultural practices (Pelosi et al., 2014). The biggest threat to soil health is pesticides and synthetic chemicals including fertilizers (Miglani and Bisht, 2019). The presence of contaminants in soil may cause stress to the individual which can divert energy from reproduction, burrowing activity and growth (Pelosi et al., 2014). The use of body mass change as a biomarker is thought to be ecologically relevant, as high losses in body mass are thought to lead to negative effects on survival and reproduction (Dittbrenner et al., 2010). These biomass changes could be a good indicator of chemical stress and link chemical effects to energy dynamics and, ultimately, to growth inhibition (Shi et al., 2007; Wu et al., 2012).

Several studies demonstrated that the application of chemical fertilizers as pulverization or powder can have negative effect on earthworm populations (Reinecke and Reineke, 2004; Rai et al., 2014). Weight loss appears to be a valuable indicator of physiological stress, related to the degree of intoxication and time of exposure (Van Gestel et al., 1995; Frampton et al., 2006). Our results showed an inhibitory effect of fertilizer on the gain of weight of $A$. caliginosa juvenile. Some studies have shown that growth of earthworms appeared to be more severely affected at juvenile stage than at adult stage (Zhou et al., 2008). It is reported that the use of inorganic fertilizer influences the biomass of earthworms (Lalthanzara and Ramanujam, 2010). The harmful effect of inorganic fertilizers has been reported to be due to its strong acidic and toxic effect of ammonia on earthworms (Donahue, 2001). It can be interpreted as indication of general health (Olvera-Velona et al., 2008). Robert (2008) reported that nitrogen containing fertilizers like NPK fertilizer are repellant to snails and insects. According to him, the fertilizer act as a repellant by inhibiting feeding and disrupting growth. El-Deeb et al. (2017), showed that three types of NPK fertilizers (high nitrogen, high phosphorus and balanced) treatment can influence Biomphalaria alexandrina snail growth, while Ragab and Shoukry (2006) reported that sublethal concentrations of urea had a stronger effect on the growth rate of the same species than sublethal concentrations of ammonium nitrate. Meanwhile, Abdel-Hamid et al. (1998) observed that urea and ammonium nitrate reduced the growth of juvenile B. alexandrina snails. $\mathrm{Wu}$ et al. (2020) reported that soil $\mathrm{pH}$ due to the increasing $\mathrm{N}$ fertilizer applications had significant inhibitory effects on the growth of E. foetida earthworms. Specific growth and growth inhibition rates in all BDE-47-treated groups of $E$. foetida were significantly different from those of the controls (Xu et al., 2015).

The SGR of this earthworm in almost all the treatments during all the exposure intervals exposed to perfluorooctane sulphonate and perfluorooctanoic acid were negative (Zheng et al., 2016). Growth inhibition of earthworms exposed to lindane and deltamethrin treated soil were significantly higher than those of the controls appeared to be time-dependent, with longer exposure duration resulting in higher inhibition (Shi et al., 2007). Choo and Baker (1998) found that endosulfan and fenamiphos significantly reduced the weight of Aporrectodea trapezoids juvenile. Zhou et al. (2006) have reported that the weight of the earthworms was a more sensitive index compared to the mortality in indicating toxic effects of acetochlor and methamidophos. Helling et al. 
(2000) tested in laboratory the effect of copperoxychloride, while Yasmin and D'Souza (2007) investigated the impact of three pesticides, carbendazim, glyphosate and dimethoate on Eisenia fetida and found a significant reduction in the earthworm growth in a dose-dependent manner.

\section{Effects on biochemical composition}

Edwards (1985) reported that the dry matter of an earthworm body contains 60 to $70 \%$ protein, 7 to $10 \%$ fat, 8 to $20 \%$ carbohydrate, $2.3 \%$ minerals and variety of vitamins. Biochemical parameters in organisms exposed to toxic contaminants have been used as biomarkers and may be considered an important diagnostic tool to assess the exposure and effects of xenobiotics (McLoughlin et al., 2000). Changes in energy reserves and/or energy consumption have been used as biomarkers of toxic stress (Świątek and Bednarska, 2019). During stress, organisms need more energy to detoxify, biotransform and excrete the toxicants with the view of minimizing the toxic effects (Khalil, 2016). Very little work has been done to test the effect of fertilizers on the biochemical profile of earthworms.

Lipids play extremely important roles in the normal function of a cell. They not only serve as highly reduced storage form of energy, but they also play an intimate role in the structure of cell membranes and the organelles found in the cell (Kandil et al., 2009). Indeed, lipids are the preferred energy fuel offered to tissues when needed after carbohydrates. During periods of chronic stress, they also constitute another source of energy (Padmaja and Rao, 1994). In our study, a decrease in total lipids was noted in $A$. caliginosa earthworm treated with NPK fertilizer compared to control earthworm.

Carbohydrates are the first energy source mobilized by organisms under toxic stress (Moolman et al., 2007). Thus, it could be suggested that the body fat of earthworms contains the enzyme system necessary to convert glucose into fatty acid and glycerol and that these in turn would be incorporated into neutral phospholipids, triglycerides and phosphatidylcholines which are involved in the growth of the organism (Mosleh et al., 2003). In our research, the tested fertilizer, NPK caused a significant reduction in the energy reserves as evidenced by a reduction in carbohydrate rates. Hence, the adverse effect of atrazine on glucose levels of earthworms may contribute to the reduction of their growth rate (Mosleh et al., 2003). It should be noted that the evolution of glucose level from chlorfluazuron over the test period could be a result of activation of phosphorylase and glucose-6-phosphatase, as reported by Koundinya and Ramamurthi (1979). The exposure of E. andrei earthworm to Zn caused an increase in energy consumption at the cellular level, reflecting the relatively high energy demand of responding to toxic stress, but no effect was observed at the whole body level (Świątek and Bednarska, 2019). Some factors such as contamination by metals and soil characteristics influence glycogen, protein and lipid content in A. caliginosa with a 50\% depletion of energy reserves (Beaumelle et al., 2014).

Protein content is considered to be the building material and involved in the alteration of almost every physiological function. It is always proportional to the growth of worm (Shankerappa, 2013). The protein content of earthworms shows considerable variability between different species and between different experimental treatments in the same species, possibly due to variability in the extent of gut inclusion (Sun and Jiang, 2017). Our experiment showed a significant decrease in protein rates in A. caliginosa treated with NPK fertilizer. A lower concentration of soluble protein in treated worms with pesticides suggests that physiological compensatory mechanisms were activated to 
provide intermediates for deriving energy (Mosleh et al., 2003). Because it appears that the lower growth rate of worms may be a result of lower food intake, the reduction in protein content may be due to a catabolism of protein in response to worm energy demand, as suggested for an isopod in response to parathion (Ribeiro et al., 2001). Other studies have looked at the decrease in protein content and enzyme activities in response to agrochemicals (Ismail et al., 1997). In contrast, protein content increased significantly after exposure with TSP and the mixture in L. terrestris and no effect of sekator was reported (Mekahlia et al., 2016). This increase might indicate physiological adaptability to compensate stress and the development of cellular defenses induced by the pesticide and phosphate fertilizer impact. Furthermore, protein accumulation could be necessary to restore enzymes or lost in tissue necrosis induced by sekator or TSP exposure (Mosleh et al., 2006). Similarly, Mosleh et al. (2006) observed changes in protein content among aquatic worms Tubifex tubifex exposed to copper.

\section{Effects on biomarker responses}

The concept of a biomarker as a biological response to a chemical that indicates the degree of exposure or toxic effect is of considerable importance in environmental toxicology (Peakall, 1994). Although the activity of antioxidant enzymes may be increased or inhibited under chemical stress, there is, however, no general rule for the different enzymes (Nmaduka et al., 2018). Earthworm biomarkers have shown promise in various applications. Biomarker responses are of interest because they integrate a wide array of environmental, toxicological and ecological factors that control and modulate exposure contaminants (Arnaud et al., 2000).

Hence, biomarker responses (GPX and LDH activities) were used for evaluating the oxidative stress of earthworm A. caliginosa after short-term exposures to NPK.

$\mathrm{LDH}$ is involved in the metabolism of carbohydrates in cells and plays a key role in maintaining the balance between the catabolism and anabolism of carbohydrates (Chen et al., 2001). In a stressful environment, LDH converts pyruvate into lactate, which in turn leads to the enhanced concentration of carboxylic acid (lactic acid) in tissues and hemolymph. The results showed that LDH activity increased in response to increased concentrations of fertilizer. Such elevation of enzyme activity could be a result of the increased synthesis of particular enzymes to defend against insecticidal stress and to increase the sources of energy production through the breakdown of energy-rich nucleotides and amino acids (Mosleh et al., 2003). A similar result was obtained for lymphocytes in a report by Liu et al. (2001). The study of Mekahlia et al. (2016) revealed that sekator and triple superphosphate fertilizer, TSP induced the biomarker responses, which was proportional to exposure time and administered dose. A significant increase in the activity of LDH was observed in Deroceras reticulatum exposed to Caselio fertilizer (Abd-El Azeem and Sheir, 2018). In addition, a significant increase has been reported in the LDH activity in the land snails (Eobania vermiculata) exposed to methomyl (Khalil, 2016).

GPx is another enzyme that can remove $\mathrm{H}_{2} \mathrm{O}_{2}$ in organisms by using reduced glutathione as a hydrogen donor. The enzymes of the glutathione redox cycle, comprising GPx and GST, play a protective role against oxidative stress (Van der Oost et al., 2003). In our study, a significant increase in GPx activity was found in $A$. caliginosa exposed to NPK fertilizer. The increase in antioxidant enzyme GPx may be an important indicator of the detoxification capacity of the earthworm (Maity et al., 2018). Interestingly, same as our results, a previous study on earthworms (Wang et al., 
2016) also found that GPx activity was induced by naphthenic acids after $1 \mathrm{~d}$ but inhibited after $14 \mathrm{~d}$ of exposure. The reasons might be that (i) GPx activity was inhibited by excessive ROS in cells; and (ii) large amounts of glutathione (GSH) were consumed to remove ROS (Cao et al., 2017). While a slight inhibition was observed in GPx activity with high phosphorus fertilizer treatment, a marked induction was obtained in GPx activity after the second week with high nitrogen fertilizer treatment (El-Deeb et al., 2017). Elumalai et al. (2007) indicate that a combined effect of different trace elements induces GST and GPx activity in the whole body tissue of A. caliginosa for the increased demand of organisms to eliminate trace elements and manage peroxidative damage by reducing the level of peroxides.

Glutathione S-transferase (GST) is a phase II detoxification enzyme modulated by xenobiotics and thus has been suggested for use as a biomarker indicative of environmental contaminant exposure (Gunderson et al., 2016). GST activity is required for the maintenance of homeostasis of the internal environment (Maity et al., 2018). It aims to combine reduced glutathione (GSH) on electrophilic compounds to facilitate their elimination (Ketterer et al., 1983). By conjugation, GST neutralizes many xenobiotics and endogenous metabolites (Hayes et al., 2005), which seems to be a possible explanation for the reduced GSH content. Interestingly, the induction of GST and GPx activity that can be correlated to the reduction in the GSH level leads to depletion in cellular antioxidant status (Radu et al., 2010). GSH deficiency might be due to the faster rate of GSH consumption for scavenging free radicals non-enzymatically or in a reaction catalyzed by GPx through the oxidation of two molecules of GSH to a molecule of GSSG (oxidized glutathione) (Van der Oost et al., 2003).

In the study of Mekahlia et al. (2016), the biomarker responses (GSH, and GST activity) were used for evaluating the oxidative stress of earthworm L. terrestris after short-term exposures to TSP and sekator. The data indicated high sensitivity of biomarkers and the changes in the GST and GSH levels reflect the oxidative stress in the earthworm. Xue et al. (2009) and Maity et al. (2008) mentioned that increased levels of GST were seen in earthworms after exposure to tetrabromobisphenol and lead, respectively. Further, Aly and Schröder (2008) showed that the GST conjugation rate in Eisenia foetida varied using two different herbicides namely fenoxaprop and metolachlor.

\section{Conclusion}

Soil organisms are exposed to a wide variety of environmental pollutants. Earthworms are significantly influenced by environmental stress, and because of their sensitive metabolic and physiological changes. The results obtained showed that the NPK fertilizer inhibited the increase in weight of A. caliginosa, which could be due to the repulsion of the contaminated food. This fertilizer also reduced content of proteins, lipids and carbohydrates in the whole body and caused the activation of the system of detoxification, traduced by an increase of the specific activity of GPx, LDH and GST and a decrease of GSH. Earthworms are useful as test organisms to assess the toxicity of chemical stressors.

Further experiments are warranted to evaluate if these effects will occur in other organisms and can cause chronic effects after more prolonged exposure as well as on other resistance mechanisms mainly detoxification enzymes, histological changes, reproduction and residue accumulation in earthworms. 
Acknowledgements. This study was supported by the National Fund for Scientific Research to Pr. N. Soltani (Laboratory of Applied Animal Biology, Badji Mokhtar University, Annaba) and the Ministry of High Education and Scientific Research of Algeria (PRFU Project to Dr. S. Tine).

\section{REFERENCES}

[1] Abbiramy, K. S. K., Ross, P. R. (2013a): Determination of acute toxicity of NPK fertilizers to Eisenia foetida using a simple paper contact method. - Int. J. Sci. Res. 2(2): 415-417.

[2] Abbiramy, K. S. K., Ross, P. R. (2013b): Validation of tropical artificial soil ecotoxicological studies on Eisenia foetida against combine fertilizers. - Int. J. Innovative. Res. Studies. 2(7): 212-227.

[3] Abd-El Azeem, H. H., Sheir, S. K. (2018): Impacts of the plant fertilizer, Caselio on the slug, Deroceras reticulatum (Gastropoda, Stylommatophora): laboratory studies. - Res. J. Pharm. Biol. Chem. Sci. 9(1): 386-396.

[4] Abdel-Hamid, A. Z., Farrag, E., Rizk, M., Omar, M., Mantawy, M. M. E. (1998): Effect of nitrogen, sulpher and phosphorus containing fertilizers and organophosphorus insecticide on reproduction of Biomphalaria alexandrina snails. - Egypt. J. Pharm. Scie. 38: 147-158.

[5] Aly, M. A., Schröder, P. (2008): Effect of herbicides on glutathione S-transferases in the earthworm, Eisenia fetida. - Environ. Sci. Poll. Res. Inter. 15: 143-149.

[6] Arnaud, A. C., Saint-Denis, M., Narbonne, J. F., Soler, P., Ribera, D. (2000): Influences of different standardized test methods on biochemical responses in the earthworm Eisenia fetida. - Soil. Biol \& Biochem. 32(1): 67-73. DOI: 10.1016/S0038-0717(99)00130-3.

[7] Băcanu, C. S., Cristina, S. D., Iuliana Manuela, D. I., Silvius, S. (2019): Agricultural production, soil quality and fertilizer used in Braila County, Romania. - Res. Agr. Agron. 9. DOI: 10.5171/2019.970358.

[8] Beaumelle, L., Lamy, I., Cheviron, N., Hedde, M. (2014): Is there a relationship between earthworm energy reserves and metal availability after exposure to field-contaminated soils? - Environ. Poll. 191: 182-189.

[9] Bhattacharya, A., Sahu, S. K. (2014): Lethal effect of urea on soil biota: a laboratory study on earthworm (Drawida willsi). - J. Biodivers. Environ. Sci. 4(6): 64-72.

[10] Bhattacharya, A., Sahu, S. K. (2016): Acute toxicity of NPK fertilizer on soil ecosystem using earthworm, Drawida willsi as a test specimen. - Int. J. Adv. Pharm. Biol. Chem. 5(3): 233-238.

[11] Bouazdia, K., Habes, D. (2017): Earthworm species identified in the region of Tebessa (Eastern Algeria). - Int. J. Zool. Res. 13: 38-44. DOI: 10.3923/ijzr.2017.38.44.

[12] Bouché, M. B. (1972): Lombriciens de France: écologie et systématique. - Institut national de la recherche agronomique, Paris.

[13] Bradford, M. (1976): A rapid and sensitive method for the quantitation microgram quantities of protein utilizing the principle of protein-dye binding. - Anal. Biochem. 72: 248-254.

[14] Callaham, M. A., Blair, J. M., Todd, T. C., Kitchen, D. J., Whiles, M. R. (2003): Macroinvertebrates in North American tallgrass prairie soils: effects of fire, mowing, and fertilization on density and biomass. - Soil. Biol. Biochem. 35: 1079-1093. DOI: 10.1016/S0038-0717(03)00153-6.

[15] Cao, W., Li, M., Wu, T., Feng, F., Feng, T., Xu, Y., Sun, C. (2017): $\alpha M S H$ prevents ROS-induced apoptosis by inhibiting Foxo1/mTORC2 in mice adipose tissue. Oncotarget. 8(25): 40872-40884. DOI: 10.18632/oncotarget.16606.

[16] Chen, K., Liu, Q., Xie, L., Sharp, P. A., Wang, D. I. (2001): Engineering of a mammalian cell line for reduction of lactate formation and high monoclonal antibody production. Biotech. Bioeng. 72(1): 55-61. 
[17] Choo, L. P. D., Baker, G. H. (1998): Influence of four commonly used pesticides on the survival, growth, and reproduction of the earthworm Aporrectodea trapezoides (Lumbricidae). - Aust. J. Agr. Res. 49(8): 1297-1303. DOI: 10.1071/A98021.

[18] Curry, J. P., Dohert, P., Purvis, G., Schmidt, O. (2008): Relationships between earthworm populations and management intensity in cattle-grazed pastures in Ireland. - Appl. Soil. Ecol. 39: 58-64. DOI: 10.1016/j.apsoil.2007.11.005.

[19] Denoyelle, R., Rault M., Mazzia C., Mascle O., Capowiez Y. 2007. Cholinesterase activity as a biomarker of pesticide exposure in Allolobophora chlorotica earthworms living in apple orchards under different management strategies. - Envir. Toxicol. Chem. 26(12): 2644-2649. DOI: 10.1897/06-355.1.

[20] Dittbrenner, N., Triebskorn, R., Moser, I., Capowiez, Y. (2010): Physiological and behavioural effects of imidacloprid on two ecologically relevant earthworm species (Lumbricus terrestris and Aporrectodea caliginosa). - Ecotox. 19: 1567-1573. DOI: 10.1007/s10646-010-0542-8.

[21] Donahue, S. (2001): Agricultural management effects on earthworm populations. - Soil. Qual. Tech. Note. 11: 1-8.

[22] Dris, D., Tine-Djebbar, F., Bouabida, H., Soltani, N. (2017): Chemical composition and activity of an Ocimum basilicum essential oil on Culex pipiens larvae: toxicological, biometrical and biochemical. - South African Journal of Botany. 113: 362-369.

[23] Duchateau, G., Florkin, M. (1959): Sur la tréhalosémie des insectes et sa signification. Arch. Insect. Biochem. Physiol. 67: 306-314.

[24] Edwards, C. A. (1985): Production of feed protein from animal waste by earthworms. Phil. Trans. R. Soc. Lon. B. 310: 299-307.

[25] Edwards, C. A., Bohlen, P. J. (1992): The effects of toxic chemicals on earthworms. Rev. Environ. Contam. Toxicol. 125: 23-99.

[26] El-Deeb, F., Mohamed-Assem, S. M., Hasheesh, W. S. H., Hussein, R. M. A., Sayed, S. S. M. (2017): Biomarkers of oxidative stress in Biomphalaria alexandrina snails for assessing the effects of certain inorganic fertilisers. - Mollusc. Res. 37(4): 289-294. DOI: 10.1080/13235818.2017.1357783.

[27] Elumalai, M., Antunes, C., Guillhermino, L. (2007): Enzymatic biomarkers in the crab Carcinus maenas from Minho River estuary (NW Portugal) exposed to zinc and mercury. - Chemosphere. 66(7): 1249-1255.

[28] Estevez, B., N'Dayegamiye, A., Coderre, D. (1996): The effect on earthworm abundance and selected soil properties after 14 years of solid cattle manure and NPK Mg fertilizer application. - Can. J. Soil. Sci. 76: 351-355.

[29] Flohe, L., Gunzler, W. A. (1984): Analysis of glutathione peroxidase. - Methods. Enzymol. 105: 114-21.

[30] Frampton, G. K., Jansch, S., Cott-Fordsmand, S. J. J., Rombke, J., Van den Brink, P. J. (2006): Effects of pesticides on soil invertebrates in laboratory studies: a review and analysis using species sensitivity distributions. - Envir. Toxicol. Chem. 25(9): 24802489. DOI: $10.1897 / 05-438$ r.1.

[31] Gill, H. K., Garg, H. (2014): Pesticide: environmental impacts and management strategies. - Pestic. Toxic. Asp. 8: 187-230. DOI: 10.5772/57399.

[32] Goldsworthy, A. C., Mordue, W., Guthkelch, J. (1972): Studies on insect adipokinetic hormones. - Gen. Comp. Endocrinol. 18(3): 545-551. DOI: 10.1016/00166480(72)90034-2.

[33] Gunderson, M. P., Pickett, M. A., Martin, J. T., Hulse, E. J., Smith, S. S., Smith, L. A., Campbell, R. M., Lower, R. H., Boggs, A. S., Guillette, L. J. (2016): Variations in hepatic biomarkers in American alligators (Alligator mississippiensis) from three sites in Florida, USA. - Chemosphere. 155: 180-1.

[34] Habig, W. H., Pabst, M. J., Jakoby, W. B. (1974): Glutathione S-Tranferases: the first enzymatic step in mercapturic acid formation. - J. Biol. Chem. 249: 7130-7139. 
[35] Hayes, J. D., Flanagan, J. U., Jowsey, I. R. (2005): Glutathione transferases. - Annu. Rev. Pharmacol. Toxicol. 45: 51-88.

[36] Helling, B., Reinecke, S. A., Reinecke, A. J. (2000): Effects of the fungicide copper oxychloride on the growth and reproduction of Eisenia fetida (Oligochaeta). Ecotoxicol. Environ. Safety. 46(1): 108-116. DOI: 10.1006/eesa.1999.1880.

[37] Hill, B. R., Levi, C. (1954): Elevation of a serum component in neoplastic disease. Cancer. Res. 14: 513-515.

[38] Ismail, S. M., Ahmed, Y. M., Mosleh, Y. Y., Ahmed, T. M. (1997): The activities of some proteins and protein related enzymes of earthworms as biomarker for atrazine exposure. - Toxicol. Environ. Chem. 63: 141-148. DOI: 10.1080/02772249709358524.

[39] Kandil, M. A., El-Deeb, H. I., Mobarak, S. A., Eweis, E. A. (2009): Biochemical impacts of methomyl and abamectin and their binary mixtures with acetylsalicylic acid against the land snails Eobania vermiculata and Monacha obstructa. - Z. Gesamte Exp. Med. 135: 545-561.

[40] Ketterer, B., Coles, B., Meyer, D. J. (1983): The role of glutathione in detoxication. Environ. Health Perspect. 49: 59-69.

[41] Khalil, A. M. (2016): Impact of methomyl lannate on physiological parameters of the land snail Eobania vermiculata. - J. Basic. Appl. Zool. 74: 1-7.

[42] Koundinya, P. R., Ramamurthi, R. (1979): Effect of organophosphate pesticide Sumithion (Fenitrothion) on some aspects of carbohydrate metabolism in a freshwater fish, Sarotherodon (Tilapia) mossambicus (Peters). - Experientia. 35(12): 1632-1633.

[43] Lal, R. (2004): Soil carbon sequestration to migrate climate change. - Geoderma 123: 122. DOI: 10.1016/j.geoderma.2004.01.032.

[44] Lalthanzara, H., Ramanujam, S. N. (2010): Effect of fertilizer (NPK) on earthworm population in the agro-forestry system of Mizoram India. - Sci. Vis. 10(4): 159-167.

[45] Lijun, L., Xuemei, L., Yaping, G., Enbo, M. (2005): Activity of the enzymes of the antioxidative system in cadmium-treated Oxya chinensis (Orthoptera Acridoidae). Envir. Toxicol. Pharmacol. 20(3): 412-416. DOI: 10.1016/j.etap.2005.04.001.

[46] Liu, M. T., Armstrong, D., Hamilton, T. A., Lane. (2001): Expression of Mig (monokine induced by interferon- $\gamma$ ) is important in $\mathrm{T}$ lymphocyte recruitment and host defense following viral infection of the central nervous system. - J. Immunol. 166: 1790-1795. DOI: 10.4049/jimmunol.166.3.1790.

[47] Maity, S., Roy, S., Chaudhury, S., Bhattacharya, S. (2008): Antioxidant responses of the earthworm Lampito mauritii exposed to $\mathrm{Pb}$ and $\mathrm{Zn}$ contaminated soil. - Environ. Poll. 151: $1-7$

[48] Maity, S., Poráčová, J., Dey, P., Vašková, J., Vaško, L., Sedlák, V., Blaščáková, M. M. (2018): Antioxidant responses in the earthworm Aporrectodea caliginosa of eastern Slovakia: application of principal component analysis as a tool to identify metal contaminated areas. - Environ. Monitor. Assess. 190(1): 21. DOI: 10.1007/s10661-017$6377-5$

[49] Maiza, R. (2013): Sublethal effects on reproduction and biomarkers by spinosad and indoxacarb in cockroaches Blattella germanica. - Bull. Insectol. 66(1): 11-20.

[50] Marhan, S., Scheu, S. (2005): The influence of mineral and organic fertilizers on the growth of the endogenic earthworm Octolasion tyrtaeum (Savigny). - Pedobiologia 49(3): 239-249. DOI: 10.1016/j.pedobi.2004.11.002.

[51] McLoughlin, N., Yin, D., Maltby, L., Wood, R. M., Yu, H. (2000): Evaluation of sensitivity and specificity of two crustacean biochemical biomarkers. - Environ. Toxicol. Chem. 19(8): 2085-2092. DOI: 10.1002/etc.5620190818.

[52] Mekahlia, M. N., Tine, S., Amieur, H., Salhi, H. (2016): In vitro biomarker responses of earthworm Lumbricus terrestris exposed to herbicide Sekator and phosphate fertilizer. Water. Air. Soil. Pollut. 227: 15. DOI: 10.1007/s11270-015-2712-z.

[53] Miglani, R., Bisht, S. S. (2019): World of earthworms with pesticides and insecticides. Interdiscip. Toxicol. 12: 71-82. DOI: 10.2478/intox-2019-0008. 
[54] Moolman, L., Van Vuren, J. H. J., Wepener, V. (2007): Comparative studies on the uptake and effects of cadmium and zinc on the cellular energy allocation of two freshwater gastropods. - Ecotox. Environ. Safe. 68: 443-450. https://doi.org/10.1016/j.ecoenv.2006.12.017.

[55] Mosleh, Y. M., Saad, M. M., Ismail, M. T. A., Ahmed, Y. M. (2003): Comparative Toxicity and Biochemical responses of certain pesticides to the mature earthworm Aporrectodea caliginosa under laboratory conditions. - Environ. Toxicol. 18(5): 338346. DOI: 10.1002/tox.10134.

[56] Mosleh, Y. Y., Paris-Palacios, S., Biagianti-Risbourg, S. (2006): Metallothioneins induction and antioxidative response in aquatic worms Tubifex tubifex (Oligochaeta, Tubificidae) exposed to copper. - Chemosphere. 64(1): 121-128. DOI: 10.1016/j.chemosphere. 2005.10.045.

[57] Nmaduka, N. J., Samuel, U. C., Akudo, O. C. (2018): Biomarkers in Achatina achatina as ecological risk assessment models of mining activities. - Res. J. Environ. Toxicol. 12: 6372.

[58] OECD (2006): Guideline for Testing of Chemicals Test 201: Freshwater Alga and Cyanobacteria, Growth Inhibition Test. - Organization for Economic Cooperation and Development (OECD), Paris.

[59] Olvera-Velona, A., Capowiez, Y., Mascle, O., Ortiz-Hernandez, L., Benoit, P. (2008): Assessment of the toxicity of ethylparthion to earthworms (Aporrectodea caliginosa) using behavioural, physiological and biochemical markers. - Appl. Soil. Ecol. 40(3): 476483. DOI: 10.1016/j.apsoil.2008.07.002.

[60] Padmaja, R. J., Rao, M. B. (1994): Effect of an organochlorine and three organophosphate pesticides on glucose, glycogen, lipid, and protein contents in tissues of the freshwater snail Bellamya dissimilis (moiler). - Bull. Environ. Contam. Toxicol. 53: 142-148.

[61] Peakall, D. B. (1994): The role of biomarkers in environmental assessment (1). Introduction. - Ecotoxicol. 3(3): 157-160.

[62] Pelosi, C. (2008): Modelisation de la dynamique d'une population de vers de terre Lumbricus terrestris au champ. - PhD thesis, l'Institut des Sciences et Industries du Vivant et de l'Environnement (Agro Paris Tech), France.

[63] Pelosi, C., Barot, S., Capowiez, Y., Hedde, M., Vandenbulcke, F. (2014): Pesticides and earthworms: a review. - Agro. Sustain. Dev. 34(1): 199-228. DOI: 10.1007/s13593-0130151-z.

[64] Radu, M., Munteanu, M. C., Petrache, S., Serban, A. I., Dinu, D., Hermenean, A., Sima, C., Dinischiotu, A. (2010): Depletion of intracellular glutathione and increased lipid peroxidation mediate cytotoxicity of hematite nanoparticles in MRC-5 cells. - Acta. Biochim. Pol. 57: 355-360.

[65] Ragab, F. M. A., Shoukry, N. M. (2006): Influence of certain fertilizers on the activity of some molluscicides against Biomphalaria alexandrina and Lymnaea natalensis snails. J. Egypt Soc. Parasitol. 36(3): 959-977.

[66] Rai, N., Ashiya, P., Rathore, D. S. (2014): Comparative study of the effect of chemical fertilizers and organic fertilizers on Eisenia foetida. - Int. J. Innov. Res. Sci. 3(5): 1299112998.

[67] Reinecke, A. J., Reinecke, S. A. (2004): Earthworm as Test Organisms in Ecotoxicological Assessment of Toxicant Impacts on Ecosystems. - In: Edwards, C. A. (ed.) Earthworm Ecology, CRC Press LLC: Boca Raton, FL, pp. 299-320.

[68] Reinecke, S. A., Reinecke, A. J. (2007): The impact of organophosphate pesticides in orchards on earthworms in the Western Cape, South Africa. - Ecotoxicol. Envir. Safe. 66(2): 244-251. DOI: 10.1016/j.ecoenv.2005.10.006.

[69] Ribeiro, S., Sousa, J. P., Nogueira, A. J. A., Soares, A. M. V. M. (2001): Effect of endosulfan and parathion on energy reserves and physiological parameters of the 
terrestrial isopod Porcellio dilatatus. - Ecotoxicol. Environ. Saf. 49(2): 131-138. DOI: 10.1006/eesa.2001.2045.

[70] Robert, J. B. (2008): Environmental horticulture. Institute of Food and Agriculture Sciences, University of Florida, Gainesville, Florida. - Organic. Farming. 326: 11-12.

[71] Shankerappa, S. (2013): Chemical composition like protein, lipid and glycogen of local three species of earthworms of Gulbarga city, Karnataka India. - Inter. J. Adv. Res. Tech. 2(7): 73-97.

[72] Shi, Y., Shi, Y., Wang, X., Lu, Y., Yan, S. (2007): Comparative effects of lindane and deltamethrin on mortality, growth, and cellulose activity in earthworms (Eisenia fetida). Pestic. Biochem. Physiol. 89: 31-38. DOI: 10.1016/j.pestbp.2007.02.005.

[73] Shibko, S., Koivistoinen, P., Tratnyek, C. A., Newhall, A. R., Friedman, L. (1967): A method for sequential quantitative separation and determination of protein, RNA, DNA, Lipid, and Glycogen from a single rat liver homogenate or from a subcellular fraction. Anal. Biochem. 19: 514-528.

[74] Shruthi, N., Biradar, A. P., Muzammil, S. (2017): Toxic effect of inorganic fertilizers to earthworms (Eudrilus eugeniae). - J. Entomol. Zool. Stud. 5(6): 1135-1137.

[75] Sifi, K., Soltani, N. (2019): Seasonal changes of two biomarkers of oxidative stress (LDH, MDA) in the edible mollusc Donax trunculus (Mollusca: Bivalvia) from the Gulf of Annaba (Algeria): correlation with carbohydrate and lipid contents. - Mollusc. Res. 39(1): 44-52.

[76] Sims, R. W., Gerard, B. M. (1999): Earthworms. Notes for the identification of British Species. Synopses of the British Fauna (New Series) No 31 (Revised). - Published for the Linnean Society of London and The Estuarine and Coastal Sciences Association by the Field Studies Council, Shrewsbury.

[77] Sun, Z., Jiang, H. (2017): Nutritive Evaluation of Earthworms as Human Food. - In: Mikkola, H. (ed.) Future Foods. IntechOpen, London, pp.128-141. DOI: 10.5772/intechopen.70271.

[78] Świątek, M., Bednarska, A. J. (2019): Energy reserves and respiration rate in the earthworm Eisenia andrei after exposure to zinc in nanoparticle or ionic form Zuzanna. Environ. Sci. Poll. Res. 26: 24933-24945.

[79] Tindaon, F., Benckiser, G., Ottow, C. G. (2011): Side effects of nitrification inhibitors on non-target microbial processes in soils. - J. Trop. Soils. 16: 7-16. DOI: 10.5400/jts.2011.16.1.7.

[80] Van der Oost, R., Beyer, J., Vermeulen, N. (2003): Fish bioaccumulation and biomarkers in environmental risk assessment: a review. - Environm. Toxicol. Pharmacol. 13: 57-149.

[81] Van Gestel, C. A. M., Zaal, J., Dirven-Van Breemen, E. M., Baerselman, R. (1995): Comparison of two test methods for determining the effects of pesticides on earthworm reproduction. - Acta. Zool. Fennica. 196: 278-283.

[82] Wang, J., Cao, X., Chai, L., Liao, J., Huang, Y., Tang, X. (2016): Oxidative damage of naphthenic acids on the Eisenia fetida earthworm. - Environ. Toxicol. 31: 1337-1343.

[83] Weckberker, G., Cory, J. G. (1988): Ribonucleotide reductase activity and growth of glutathione-depleted mouse leukemial 1210 cells in vitro. - Cancer lettres. 40: 257-264.

[84] Wu, S. J., Wu, E. M., Qiu, L. Q., Zhong, W. H., Chen, J. M. (2011): Effects of phenanthrene on the mortality, growth, and anti-oxidant system of earthworms (Eisenia fetida) under laboratory conditions. - Chemosphere 83(4): 429-434.

[85] Wu, S. J., Zhang, H. X., Zhao, S. L., Wang, J. L., Li, H. L., Chen, J. M. (2012): Biomarker responses of earthworms (Eisenia fetida) exposed to phenanthrene and pyrene both singly and combined in microcosms. - Chemosphere. 87(4): 285-293.

[86] Wu, J., Ren, Z., Zhang, C., Motelica-Heino, M., Deng, T., Wang, H., Dai, J. (2020): Effects of soil acid stress on the survival, growth, reproduction, antioxidant enzyme activities, and protein contents in earthworm (Eisenia fetida). - Environ. Scie. Pol. Res. 27: 33419-33428. 
[87] Xu, X. B., Shi, Y. J., Lu, Y. L., Zheng, X. Q., Ritchie, R. J. (2015): Growth inhibition and altered gene transcript levels in earthworms (Eisenia fetida) exposed to 2,2',4,4'tetrabromodiphenyl ether. - Arch Environ Contam Toxicol. DOI: 10.1007/s00244-0140125-4.

[88] Xue, Y. G., Gu, X. Y., Wang, X. R., Sun, C., Xu, X. H., Sun, J., Zhang, B. G. (2009): The hydroxyl radical generation and oxidative stress for the earthworm Eisenia fetida exposed to tetrabromobisphenol A. - Ecotoxicology. 18: 693-699.

[89] Yahyaabadi, M., Hamidian, A. H., Ashrafi, S. (2018): Dynamics of earthworm species at different depths of orchard soil receiving organic or chemical fertilizer amendments. Eurasian. J. Soil. Sci. 7: 318-325. DOI: 10.18393/ejss.454506.

[90] Yasmin, S., D'Souza, D. (2007): Effect of pesticides on the reproductive output of Eisenia fetida. - Bul. Envir. Contam. Toxicol. 79(5): 529-532. DOI: 10.1007/s00128007-9269-5.

[91] Yasmin, S., D'Souza, D. (2010): Effects of pesticides on the growth and reproduction of earthworm: a review. - Appl. Environ. Soil. Sci. 9. DOI: 10.1155/2010/678360.

[92] Zheng, X. Q., Shi, Y. J., Lu, Y. L., Xu, X. B. (2016): Growth inhibition and DNA damage in the earthworm (Eisenia fetida) exposed to perfluorooctane sulphonate and perfluorooctanoic acid. - Chemistry and Ecology. DOI: 10.1080/02757540.2015.1116524.

[93] Zhou, Q. X., Zhang, Q. R., Liang, J. D. (2006): Toxic effects of acetochlor and methamidophos on earthworm Eisenia fetida in phaiozem, northeast China. - J. Envir. Sci. 18(4): 741-745.

[94] Zhou, S., Duan, C., Wang, X., Michelle, W. H. G., Yu, Z., Fu, H. (2008): Assessing cypermethrin-contaminated soil with three different earthworm test methods. - J. Envir. Sci. 20(11): 1381-1385. DOI: 10.1016/S1001-0742(08)62236-6. 